\title{
Effects of Flourensia cernua ingestion on intake, digesta kinetics, and ruminal fermentation of sheep consuming tobosa
}

\author{
D.W. KING, R.E. ESTELL, E.L. FREDRICKSON, K.M. HAVSTAD, J.D. WALLACE, \\ AND L.W. MURRAY
}

\begin{abstract}
Authors are beef nutritionist, 9101 63rd Ave., Dickinson, N.D. 58602; research animal scientist, USDA-ARS, Jornada Exp. Range, Las Cruces, N.M. 88003; research animal scientist, USDA-ARS, Jomada Exp. Range, Las Cruces, N.M.; research leader, USDA-ARS, Jomada Exp. Range; professor, Animal and Range Science Dept., New Mexico State Univ., Las Cruces, N.M.; and associate professor, Exp. Statistics Dept., New Mexico State Univ., Las Cruces, N.M., respectively. At the time of the research, the senior author was a graduate research assistant, Animal and Range Science Dept., New Mexico State Univ., Las Cruces, N.M.
\end{abstract}

\begin{abstract}
Tarbush (Flourensia cernua DC.) contributes substantially to the Chihuahuan Desert shrub biomass, but is browsed sparingly by livestock. This study was designed to assess nutritional benefits and/or toxicosis of ingestion of pre-bloom tarbush leaves by sheep fed a low quality native grass diet. Sixteen ruminally cannulated sheep (46 kg) housed in individual pens were randomly assigned to 1 of 4 treatments for 28 days. Treatments were ground tobosa grass (Pleuraphis mutica BuckI.) substituted with 0, 10, 20, or $30 \%$ (dry matter basis) whole tarbush leaves (19\% CP). At 20 and $30 \%$ of the diet, tarbush increased $(P=0.0049)$ dry matter intake during week 3 , and sheep consuming $30 \%$ tarbush tended to increase dry matter intake during week $2(P=0.0559)$. Dietary tarbush did not affect any variable associated with ruminal fluid kinetics, particulate digesta kinetics, or in situ degradation rates of tobosa dry matter or neutral detergent fiber $(P>0.05)$. Molar butyrate proportions $(P=0.0032)$ and total volatile fatty acid concentrations $(P=0.0064)$ were greater for the $30 \%$ tarbush treatments. Ruminal ammonia was greater $(P<0.0029)$ at 6,8 , and 12 hours postfeeding for the $30 \%$ tarbrush treatment. Sheep lost body weight regardless of treatment; however, sheep not fed tarbush tended $(P=0.0945)$ to lose more weight. Serum clinical profiles (day $0,7,15$, and 21 ) confirmed nutritional stress but did not suggest toxicosis.
\end{abstract}

Key Words: browse, dry matter intake, Flourensia cernua, Pleuraphis mutica, passage rate, tarbush.

Tarbush (Flourensia cernua DC.) is an aridland shrub rapidly increasing in the Chihuahuan Desert region of the United States and Mexico (Buffington and Herbel 1965), dominating more than 45 million ha (O'Laughlin 1975). Tarbush constitutes a substantial biomass that is only occasionally browsed by free ranging livestock (Nelson et al. 1970, Anderson et al. 1991), but has been

The authors gratefully acknowledge the assistance of Randy Leslie, Larry Shupe, Roy Libeau, and Linda Saar.

Mtanuscript accepted 8 Sept 95. found in moderate amounts $(12 \%)$ in esophageal masticate of steers (Anderson and Holechek 1983).

Previous research regarding tarbush focused on toxicity or identification of chemical constituents. Mathews (1944) conducted short term studies to characterize toxicosis of sheep and goats consuming fresh tarbush fruits, which proved fatal at $1 \%$ of body weight (BW); however, green leaves did not appear toxic. Hailey et al. (1966) observed multiple fatalities of starving antelope forced to consume only tarbush.

Potential exists for tarbush, with its high protein content (Nelson et al. 1970), to serve as a protein source for grazing animals during periods when it is not in bloom. However, tarbush contains terpenes and phenolic compounds (Estell et al. 1994, Unpublished data, Estell et al.), which may alter digestion and/or cause toxicosis. The objective of this study was to evaluate dry matter intake, digestion, passage rate, ruminal fermentation, and toxicological consequences of moderate consumption (up to $30 \%$ ) of tarbush leaves by sheep fed a low quality tobosa grass (Pleuraphis mutica Buckl.) diet. Effect of tarbush on $\mathrm{N}$ balance was examined in a companion study (King et al. 1996).

\section{Materials and Methods}

Tarbush and Tobosa Harvest

Whole tarbush plants (pre-bloom) were collected from the USDA-ARS, Jornada Experimental Range (JER), $35 \mathrm{~km}$ north of Las Cruces, N.M. during August 1991. Shrubs were air-dried for 4 days with forced-air, and leaves were scparated from stems by thrashing and winnowing.

Tobosa grass, which grows in association with tarbush, was collected during August 1991 near the tarbush collection site. Mowed grass was allowed to field dry for 12 hours, and was then stored loose under shelter. The tobosa was mature and contained 30 to $50 \%$ dead material. About $95 \%$ of the collection was tobosa, with the remainder primarily Desert Holly (Perezia nana Gray). Tobosa was ground to pass a $2.54 \mathrm{~cm}$ screen using a commercial mix-mill. 


\section{Experimental Protocol}

Sixteen ruminally cannulated fine wool Polypay $\times$ Rambouillet (15 wethers, 1 ewe) were randomly allotted to 1 of 4 treatments: $100 \%$ ground tobosa (control), or tobosa substituted with 10,20 , or $30 \%$ whole tarbush leaves on a dry matter basis (dmb). Surgical procedures and animal care were in accordance with guidelines established by the New Mexico State University Institutional Animal Care and Use Committee. The $10 \%$ tarbush treatment was designed to approximate the maximum amount reported to be consumed by free ranging steers (Anderson and Holechek 1983), and the 20 and $30 \%$ treatments were included to assess effects of dietary tarbush at levels above those typically consumed by livestock. Sheep ranged in age from 8 to 12 months with an average initial fasting body weight (BW) of $46.1 \mathrm{~kg}$ ( $\mathrm{SE}=1.7$ ).

Sheep were housed in individual indoor pens $(2.4 \times 4.7 \mathrm{~m})$ and provided with 12 hours of light daily. Sheep received tobosa plus $30 \%$ alfalfa during a 5 day adjustment to pens, and were then fed experimental diets for 28 days. Sheep were fed at 0700 and 1600 hours daily. Diets were fed at restricted levels (approximately 95\% of ad libitum; established during adjustment period) during the first week to minimize orts and reduce sorting of tarbush leaves. Diets were offered at $110 \%$ of ad libitum (established during adjustment period and adjusted daily) for the remaining 3 weeks. Water and trace mineral salt blocks ( $\mathrm{NaCl} 96-99 \%, \mathrm{Mn}>$ $0.2 \%, \mathrm{Fe}>0.1 \%, \mathrm{Mg}>0.1 \%, \mathrm{~S}>0.05 \%, \mathrm{Cu}>0.025 \%$, $\mathrm{Co}>$ $0.01 \%, \mathrm{Zn}>0.008 \%$, and $\mathrm{I}>0.007 \%$; United Salt Corp., Houston, Tex.) were provided ad libitum and water consumption was monitored between days 15 and 28 .

\section{Diet Chemical Analyses}

Grab samples of tobosa and tarbush were collected at each feeding and composited by week. Orts were weighed before the morning feeding and a subsample composited by sheep each week. Diet and ort samples were ground to pass a 2-mm screen using a Wiley mill. Dry matter (DM) and ash were determined by standard procedures (AOAC 1984). Neutral detergent fiber (NDF), acid detergent fiber (ADF), acid detergent lignin (ADL), and acid detergent insoluble nitrogen (ADIN) analysis followed nonsequential procedures of Goering and Van Soest (1970). Nitrogen content of diet ingredients and orts was determined by the Kjeldahl method (AOAC 1984). Total phenolic content of tarbush and tobosa was determined by the Folin-Denis method (AOAC 1984) while condensed tannin content was analyzed by the vanillin/ $\mathrm{HCl}$ procedure of Burns (1971) as modified by Price et al. (1978).

\section{Ruminal Digesta Kinetics and Fermentation}

Cobalt-ethylenediaminetetraacetate (Co-EDTA) was dosed (50 $\mathrm{ml}$, Uden et al. 1980) via ruminal cannula before the morning feeding on day 15. Ruminal samples were collected from mast in the dorsal sac at 0 (before dosing), 2, 4, 6, 8, 12, 24, and 36 hours postdosing. Ruminal $\mathrm{pH}$ was determined immediately with a combination electrode (model 13-620-111, Fisher Scientific, Pittsburgh, Penn.) and fluid (100 ml) was strained through 4 layers of cheesecloth, acidified with $1 \mathrm{ml}$ of $7.2 \mathrm{~N} \mathrm{H}_{2} \mathrm{SO}_{4} 100 \mathrm{ml}^{-1}$ and stored frozen. Samples were subsequently thawed and centrifuged at $10,000 \times \mathrm{g}$ for $10 \mathrm{~min}$. Supernatant was analyzed for Co concentration using atomic absorption spectrophotometry with an air/acetylene flame (McCollum and Galyean 1985), and ruminal ammonia using the spectrophotometric phenol-hypochlorite assay (Broderick and Kang 1980). A third aliquot of super- natant was analyzed for volatile fatty acids (VFA) using 2-ethyl butyric acid as an internal standard (Goetsch and Galyean 1983). Ruminal fluid dilution rate was calculated by regressing the natural logarithm of Co concentration on time postdosing, and ruminal fluid volume was estimated by dividing the Co dose by the extrapolated Co concentration at 0 hours postdosing.

On day 17, animals were dosed intraruminally with $15 \mathrm{~g}$ (dmb) of hydrated ytterbium $(\mathrm{Yb})$ labeled (Teeter et al. 1984) tobosa hay. Rectal grab fecal samples were obtained at 0 (before dosing), $4,8,12,16,20,24,28,32,36,42,48,54,60,72,84,96$, 108 , and 120 hours postdosing and stored frozen. Fecal samples were subsequently thawed, dried at $50^{\circ} \mathrm{C}$ for 72 hours, and ground $(1 \mathrm{~mm})$. Ytterbium was extracted using EDTA (Hart and Polan 1984) and measured by atomic absorption spectrophotometry with a nitrous oxide/acetylene flame. Fecal $\mathrm{Yb}$ excretion curves were fitted to a 1-compartment model (Krysl et al. 1985) to estimate particulate passage rate, retention time, fecal output, and gastrointestinal dry matter (DM) fill.

\section{In Situ Degradability}

Rate and extent of tobosa dry matter (DM), tobosa neutral detergent fiber (NDF) tarbush DM, and tarbush $\mathrm{N}$ disappearance were measured in situ on days 20 through 29 . Incubation times were $0,6,12,18,24,48,72$, and 96 hours for tarbush, and the same series plus a 120 hour incubation for tobosa. One gram of ground $(2 \mathrm{~mm})$ sample was placed in a tared dacron bag $(5 \times 10$ $\mathrm{cm}$, pore size $<50$ microns, Ankom, Fairport, N.Y.) and incubated in duplicate with a blank for each incubation time (Nocek 1988). Bags were tied with plastic cable ties $2 \mathrm{~cm}$ from the bag top, providing a surface area of approximately $40.5 \mathrm{~cm}^{2}$ and a sample to surface area ratio of $25 \mathrm{mg} / \mathrm{cm}^{2}$. Dacron bags were suspended in the rumen in a $36 \times 42 \mathrm{~cm}$ polyester mesh laundry bag attached to a $50 \mathrm{~cm}$ nylon cord. Upon removal, mesh bags containing dacron bags were immersed in ice water to halt microbial digestion and then agitated by hand until rinse water remained clear. Bags were allowed to drain and stored frozen. Bags were later thawed and dried in a forced-air oven at $50^{\circ} \mathrm{C}$ for 24 hours and $100^{\circ} \mathrm{C}$ for 1 hour, desiccated for $30 \mathrm{~min}$, and then weighed.

Dacron bags containing tobosa residue were sequentially used to determine neutral detergent fiber (NDF) content by refluxing multiple bags for 1 hour in $100 \mathrm{ml}$ of solution $\mathrm{g}^{-1}$ of residue, rinsing with hot water and acetone, rinsing in a conventional washing machine, and drying for 12 hours at $100^{\circ} \mathrm{C}$ (Moore et al. 1987). In situ digestion rate, lag time, and potential extent of digestion were calculated for tobosa and tarbush dry matter (DM) and tobosa NDF (Mertens and Loften 1980).

Nitrogen content of tarbush residue was measured as described by Moshtagi Nia and Ingalls (1992), using standard kjeldahl analysis of dacron bags with or without (blank) sample residue. The $\mathrm{N}$ disappearance of tarbush was fitted to the exponential equation of Drskov and McDonald (1979).

\section{Blood Sampling}

Blood (approximately $10 \mathrm{ml}$ ) was collected on days $0,7,15$, and 21 via jugular venipuncture before the 0700 hour feeding. Blood was allowed to clot at room temperature for $30 \mathrm{~min}$, centrifuged at $2,300 \times \mathrm{g}$ for $15 \mathrm{~min}$ at $4^{\circ} \mathrm{C}$, and serum was decanted and frozen $\left(-10^{\circ} \mathrm{C}\right)$. Serum was analyzed for metabolite, enzyme, and electrolyte levels with an automated multichannel analyzer (Chem-30; Southwest Laboratories, Las Cruces, N.M.). 


\section{Statistical Analyses}

Data were analyzed as a completely random design. Using a randomized complete block design, it was initially determined that neither age nor sex differences were significant $(P>0.05)$ or added unwanted variability to the experiment; hence, blocks were climinated. Statistical analysis of variance was conducted using GLM procedure of SAS Institute (1989). Treatment means were separated by predicted difference when a significant F-test $(P<0.05)$ for the overall model was observed.

For variables collected over time, data were analyzed as repeated measures using a split plot design (Gill and Hafs 1971), with treatment in the main plot (sheep within treatment as error term) and time in the sub-plot. Means were separated using predicted difference (SAS Institute 1989) when a significant $F$-test $(P<0.05)$ was observed.

\section{Results}

\section{Chemical Analysis of Diets}

The nutritional value of tobosa was relatively poor: $5.9 \%$ crude protein (CP) $0.3 \%$ acid detergent insoluburn (ADIN) $80 \%$ neutral detergent fiber (NDF) 57\% acid detergent fiber (ADF) and $13 \%$ acid detergent light (ADL) (dmb). Tarbush leaves were relatively high in $\mathrm{CP}$ and low in fiber (18.9\% CP, 0.4\% ADIN, 33\% NDF, $24 \% \mathrm{ADF}$, and $10 \% \mathrm{ADL}$ (dmb). Dry tarbush leaves contained 54 $\mathrm{mg} \mathrm{g}^{-1}$ of total phenolics and $0.40 \mathrm{mg} 100 \mathrm{mg}^{-1}$ of condensed tannins (catechin equivalents), compared to $12 \mathrm{mg} \mathrm{g}^{-1}$ of total pheno-

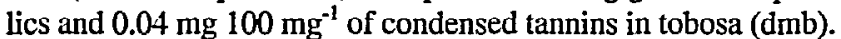

Differences between calculated CP content of feed offered and CP content of orts indicated some sorting by sheep on 20 and $30 \%$ treatments. However, orts were usually low except during week 1 and percent tarbush consumed was similar in magnitude to percent tarbush offered except during week 1 . Actual percent tarbush consumed for the 10,20, and $30 \%$ tarbush treatments, respectively, was 11,14 , and $22 \%$ (week 1), 10, 17, and $30 \%$ (week 2), 10, 19, and $30 \%$ (week 3 ), and 12,20 , and $30 \%$ (week 4).

\section{Voluntary Dry Matter and Water Intake}

During week 3, dry matter intake (DMI) for 20 and 30\% tarbush treatments was greater $(P=0.0049)$ than 0 and $10 \%$ treatments (Table 1). Sheep consuming 30\% tarbush tended to have greater DMI during weeks $2(P=0.0559)$ and $4(P=0.1453)$. Only during week 1 was DMI of sheep consuming $30 \%$ tarbush below $2 \%$ of body weight (BW) or numerically less than other treatments. However, all sheep exhibited intake fluctuations, regardless of treatment, and each sheep went off feed for 1 to 3 days at least once during the trial. Feed consumption by all sheep declined markedly between weeks 3 and 4 (Table 1). This abrupt DMI depression coincided with ruminal insertion of nylon bags on day 20.

Water intake differed $(P<0.0091)$ during weeks 3 and 4 (Table 1), with sheep fed $10 \%$ tarbush consuming more water than sheep on other treatments. Some ruminal fluid leakage occurred due to fistulation, and a sheep fed $10 \%$ tarbush lost its cannula once during the study.

\section{Digesta Kinetics}

Proportion of tarbush in the diet did not affect ruminal fluid $(P>$ $0.05)$ or particulate $(P>0.05)$ dynamics measured (Table 2$)$.
Table 1. Dry matter intake (DMI), water intake, and body weight (BIV) change of sheep fed a low quality tobosa diet $(5.9 \% \mathrm{CP})$ with $0,10,20$, or $30 \%$ of the dietary dry matter as tarbush (18.9\% CP).

\begin{tabular}{|c|c|c|c|c|c|c|}
\hline \multirow[b]{2}{*}{ Period } & \multicolumn{4}{|c|}{$\overline{\text { Treatment }}$} & \multirow[b]{2}{*}{$S E^{l}$} & \multirow[b]{2}{*}{$O S L^{2}$} \\
\hline & $\begin{array}{c}0 \% \\
\text { Tarbush }\end{array}$ & $\begin{array}{c}10 \% \\
\text { Tarbush }\end{array}$ & $\begin{array}{c}20 \% \\
\text { Tarbush }\end{array}$ & $\begin{array}{c}30 \% \\
\text { Tarbush }\end{array}$ & & \\
\hline DMI & \multicolumn{6}{|c|}{$\ldots\left(\mathrm{g} \mathrm{kg}^{-1}\right) \ldots \ldots$} \\
\hline Week 1 & 12.3 & 12.0 & 16.6 & 14.8 & 1.88 & 0.3024 \\
\hline Week 2 & 15.5 & 15.6 & 18.3 & 20.8 & 1.40 & 0.0559 \\
\hline Week 3 & $15.8^{\mathrm{a}}$ & $17.1^{\mathrm{a}}$ & $20.4^{b}$ & $22.1^{\mathrm{b}}$ & 1.07 & 0.0049 \\
\hline Week 4 & 11.2 & 14.5 & 13.6 & 19.0 & 2.23 & 0.1453 \\
\hline \multicolumn{7}{|c|}{ Water Intake } \\
\hline Week 3 & $2.8^{\mathrm{a}}$ & $4.5^{b}$ & $3.7^{\mathrm{ab}}$ & $4.1^{b}$ & 0.38 & 0.0091 \\
\hline Week 4 & $2.3^{\mathfrak{a}}$ & $4.5^{\mathrm{b}}$ & $3.0^{\mathrm{a}}$ & $3.0^{\mathrm{a}}$ & 0.31 & 0.0001 \\
\hline BW chan & & & 0 & & $-\ldots$ & \\
\hline Mean & -6.1 & -1.4 & -2.3 & -1.7 & 1.35 & 0.0945 \\
\hline
\end{tabular}

3.6 Least Square means within row without a common superscript differ $(\mathrm{P}<0.05)$.

${ }^{1}$ Standard error of Least Square Means, $n=16$.

${ }^{2}$ Observed significance level of $F$-statistic for effect of treatment.

Rumen volume tended to be greater $(P=0.1226)$ for sheep consuming $10 \%$ tarbush, which could be associated with their increased water intake. Particulate passage rate tended $(P=0.0665)$ to be faster for sheep consuming $20 \%$ vs 0 or $10 \%$ tarbush.

\section{In Situ Disappearance}

In situ ruminal dry matter (DM) and neutral detergent fiber (NDF) disappearance rates of tobosa (Table 3$)$ were similar $(P>0.05)$ across treatments. In situ NDF disappearance was slow $(<4.4 \%$ hour ${ }^{-1}$ ) and the potentially degradable fiber was below $33 \%$, further substantiating the poor diet quality of tobosa suggested by chemical analysis.

Dietary tarbush did not affect $(P>0.05)$ in situ rate of tarbush dry matter (DM) disappearance or the potentially degradable fraction (Table 3), both of which were high regardless of treatment. Large 0 hour losses from bags containing tarbush added variability and inflated calculated rates of disappearance, which may explain similar rates of disappearance with large numerical differences. For example, tarbush DM disappearance rate was $8.5 \%$ hour ${ }^{-1}$ for sheep fed $10 \%$ tarbush and $15.5 \%$ for those consuming $30 \%$ tarbush.

Dietary tarbush did not influence $(P>0.05)$ disappearance rate or proportion of degradable tarbush $N$ (Table 4). Rate of tarbush $\mathrm{N}$ disappearance was greater than $5 \%$ hour $^{-1}$ for all diets and the potentially degraded fraction was greater than $92 \%$, and $60 \%$ when corrected for 0 hour losses. Even though highly digestible, nearly $70 \%$ of the tarbush $\mathrm{N}$ was in the slowly degradable fraction.

\section{Ruminal Fermentation}

Tarbush did not appear to affect ruminal $\mathrm{pH}$. Ruminal $\mathrm{pH}$ pooled across hours did not differ $(P>0.05)$ among treatments (Table 5). At all collection times, ruminal pH exceeded 6.2 (the value reported to inhibit cellulolytic bacteria, Orskov 1992).

A treatment by hour interaction was detected $(P=0.0001)$ for ruminal ammonia concentration. Ruminal ammonia concentrations were not different among treatments $(P>0.05)$ at 0 and 2 hours postfeeding (19.5 and $18.5 \mathrm{mg} \mathrm{dl}^{-1}$, respectively). At 4 hours postfeeding, ammonia concentrations tended $(P=0.0921)$ 
Table 2. Ruminal fluid and particulate dynamics of sheep fed a low quality tobosa diet $(5.9 \% \mathrm{CP})$ with 0 , 10, 20, or 30\% of the dietary dry matter (DM) as tarbush (18.9\% CP).

\begin{tabular}{|c|c|c|c|c|c|c|}
\hline \multirow[b]{2}{*}{ Item } & \multicolumn{4}{|c|}{ Treatments } & \multirow[b]{2}{*}{$S E^{I}$} & \multirow[b]{2}{*}{$O S L^{2}$} \\
\hline & $\begin{array}{c}0 \% \\
\text { Tarbush }\end{array}$ & $\begin{array}{c}10 \% \\
\text { Tarbush }\end{array}$ & $\begin{array}{l}20 \% \\
\text { Tarbush }\end{array}$ & $\begin{array}{c}30 \% \\
\text { Tarbush }\end{array}$ & & \\
\hline $\begin{array}{l}\text { Ruminal fluid } \\
\text { dilution rate, \%o } \\
\text { hour }\end{array}$ & 6.2 & 6.7 & 7.2 & 7.5 & 0.71 & 0.5989 \\
\hline $\begin{array}{l}\text { Ruminal fluid } \\
\text { volume, liters }\end{array}$ & 5.1 & 6.8 & 5.8 & 5.4 & 0.42 & 0.1226 \\
\hline $\begin{array}{l}\text { Undigestible DM fill, } \\
\mathrm{g} \mathrm{kg}^{-1} \text { body weight }\end{array}$ & 17.2 & 19.6 & 15.8 & 18.5 & 1.5 & 0.3512 \\
\hline $\begin{array}{l}\text { Fecal DM output, } g \\
\text { day }^{-1}\end{array}$ & 392.0 & 414.0 & 479.0 & 448.0 & 44 & 0.5436 \\
\hline $\begin{array}{l}\text { Ruminal particulate } \\
\text { retention time, hours }\end{array}$ & 55.2 & 63.5 & 42.5 & 53.0 & 5.7 & 0.1271 \\
\hline
\end{tabular}

Standard error of Least Square Means, $n=16$.

${ }^{2}$ Observed significance level of $F$-statistic for treatment.

to be greater for sheep fed $30 \%$ tarbush $\left(22.3 \mathrm{mg} \mathrm{dl}^{-1}\right)$ than for sheep receiving 0,10 , and $20 \%$ tarbush $(16.5,16.2$, and $14.9 \mathrm{mg}$ $\mathrm{dl}^{-1}$, respectively). Treatment differences were detected at 6,8 , and 12 hours postfeeding $(P<0.05)$. Ruminal ammonia concentrations for sheep fed $0,10,20$, and $30 \%$ tarbush were 11.7, 14.9, 14.9 , and $23.6 \mathrm{mg} \mathrm{dl}^{-1}$ at 6 hours, $9.0,13.9,13.3$, and $23.8 \mathrm{mg} \mathrm{dl}^{-1}$ at 8 hours, and 10.3,14.5,12.0, and $23.4 \mathrm{mg} \mathrm{dl}^{-1}$ at 12 hours postfeeding, respectively. Sheep receiving $30 \%$ tarbush had greater $(P=0.0046)$ ruminal ammonia concentrations than sheep fed other diets at these times. Sheep fed 0, 10, and 20\% tarbush had similar $(P>0.05$ ) ruminal concentrations except at 8 hours postfeeding, when sheep fed $10 \%$ tarbush had greater ammonia concentrations $(P=0.0334)$ than controls.

A treatment by hour interaction was observed $(P=0.0419)$ for ruminal molar butyrate proportion, but the nature of the interaction was such that it did not preclude examination of the main effect of treatment. Dietary tarbush influenced molar proportions of butyrate $(P=0.0032)$ and n-valerate $(P=0.0137)$ and total ruminal volatile fatty acids (VFA) concentrations $(P=0.0064)$, but did not affect $(P>0.05)$ molar proportions of other VFA (Table 5 ). As was the case for ruminal ammonia, $30 \%$ dietary tarbush increased total VFA concentration and molar proportion of butyrate, while 0,10 , and $20 \%$ treatments did not differ $(P>0.05)$ for either variable. Sheep fed $30 \%$ tarbush had greater ruminal valerate proportions than sheep fed control or $10 \%$ tarbush treatments; however, the $30 \%$ group did not differ from the $20 \%$ treatment, which was similar to control and $10 \%$ groups $(P>0.05)$.

\section{Body Weight Changes}

Dietary tarbush did not influence body weight (BW) change $(P>$ 0.05 ) of sheep. Sheep lost BW regardless of treatment (Table 1). However, control sheep tended $(P=0.0945)$ to experience a greater BW loss $(-6.1 \mathrm{~kg})$ than sheep on diets containing tarbush $(-2.3 \mathrm{~kg})$.

Table 3. Effect of dietary tarbush on in situ rate of tobosa dry matter (DM) and neutral detergent fiber (NDF) and tarbush DM disappearance in sheep fed a low quality tobosa diet (5.9\% CP) with $0,10,20$, or $30 \%$ of the dietary DM as tarbush (18.9\% CP).

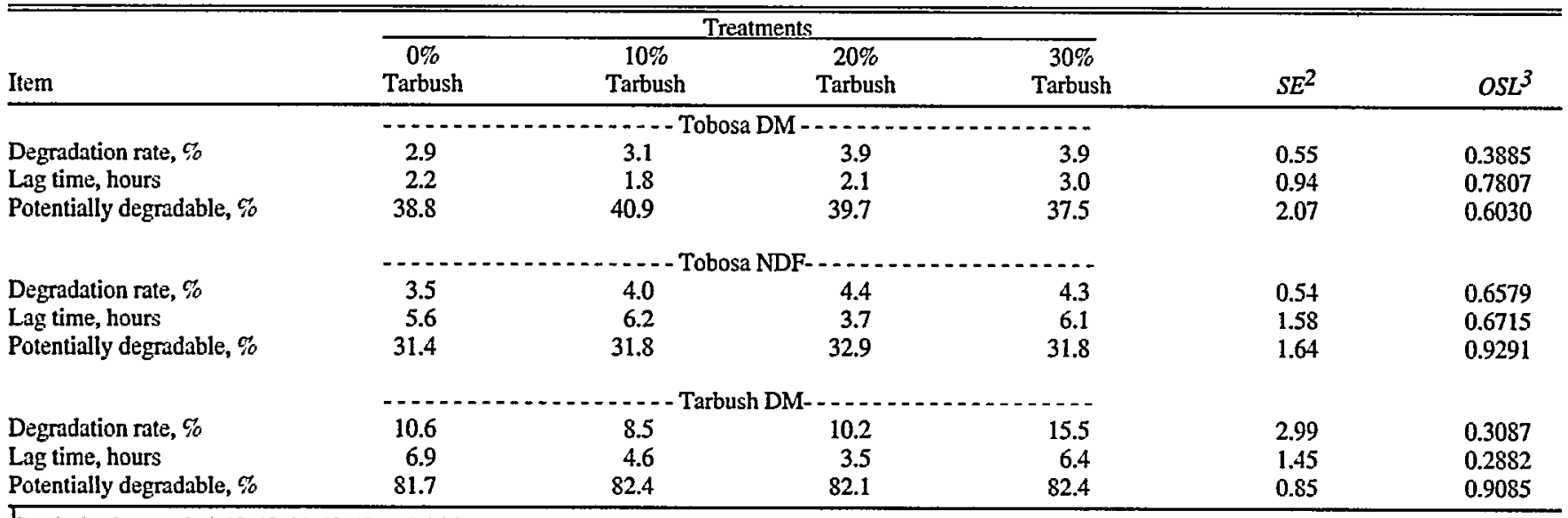

Incubation hours $=0,6,12,18,24,48,72$, and 96 for tarbush and same time plus 120 hours for tobosa. Estimates derived from model described by Mertens and Loften (1980).

${ }_{3}^{2}$ Standard error for Least Square means, $n=16$.

${ }^{3}$ Observed significance level of $F$-statistic for treatment. 
Table 4. Rate and extent of ruminal in situ disappearance of tarbush leaf ${ }^{1} \mathrm{~N}$ in sheep fed a low quality tobosa diet $(5.9 \% \mathrm{CP})$ with $0,10,20$, or $30 \%$ of the dietary dry matter as tarbush (18.9\% CP).

\begin{tabular}{|c|c|c|c|c|c|c|}
\hline \multirow[b]{2}{*}{ Item } & \multicolumn{4}{|c|}{ Treatments } & \multirow[b]{2}{*}{$S E^{2}$} & \multirow[b]{2}{*}{$O S L^{3}$} \\
\hline & $\begin{array}{c}0 \% \\
\text { Tarbush }\end{array}$ & $\begin{array}{c}10 \% \\
\text { Tarbush }\end{array}$ & $\begin{array}{c}20 \% \\
\text { Tarbush }\end{array}$ & $\begin{array}{c}30 \% \\
\text { Tarbush }\end{array}$ & & \\
\hline Slowly degradable, $C^{\prime}$ & 70.2 & 68.8 & 67.3 & 68.5 & 1.45 & 0.5199 \\
\hline Rapidly degradable, \% & 23.2 & 24.7 & 25.0 & 24.2 & 1.08 & 0.6315 \\
\hline Potentially degradable, $\%$ & 93.4 & 93.5 & 92.3 & 92.7 & 1.03 & 0.7625 \\
\hline
\end{tabular}

Incubation times $=0,6,12,18,24,48,72$, and 96 hours.

${ }^{2}$ Standard error for Least Square Means, $n=15$.

3 Observed significance level of $F$-statistic of treatment.

${ }_{4}$ Estimates derived from model described by Orskov and MeDonald (1979).

\section{Blood Chemistry}

Clinical profiles for serum (data not shown) collected on days $0,7,15$, and 21 did not indicate toxicosis. Serum triglyceride (8.9 to $13.1 \mathrm{mg} \mathrm{dl}^{-1}$ ) and blood urea levels (13.7 to $16.4 \mathrm{mg} \mathrm{dl}^{-1}$ ) were within normal ranges (Kaneko 1989), but were below those of well nourished sheep. Creatinine (1.24 to $\left.1.26 \mathrm{mg} \mathrm{dl}^{-1}\right)$, bilirubin (direct, indirect, and total ) alkaline phosphatase (165.4 to 207.8 $\mathrm{U}$ liter ${ }^{-1}$ ), and aspartate aminotransferase (52.4 to $66.9 \mathrm{U} \mathrm{liter}^{-1}$ ) concentrations were all within normal ranges (Kaneko 1989). Serum gamma-glutamyltransferase was lower $(P<0.05)$ for sheep on the $0 \%$ tarbush treatment (39.3 U liter ${ }^{-1}$ ) than for those on 10 , 20 , and $30 \%$ tarbush $\left(46.1,48.8\right.$, and $47.2 \mathrm{U} \mathrm{liter}^{-1}$, respectively); however, all values were within normal ranges (Kaneko 1989).

\section{Discussion}

Chemical analysis of diet ingredients substantiated the potential nutritional merit of tarbush leaves, especially in terms of crude protein (CP) (19\% dmb). Conversely, tobosa was below 6\% CP (dmb). Forage intake may be enhanced by protein supplementation with low quality forages (McCollum and Galyean 1985). In theory, substitution with $10 \%$ dietary tarbush should have contributed enough additional $\mathrm{N}$ to ensure dietary protein concentration was not marginal $(>7 \% \mathrm{CP}, \mathrm{dmb}$ ), assuming sorting and/or $\mathrm{N}$ availability were not problems. Sorting against tarbush leaves was observed on the 20 and $30 \%$ treatments for all but 1 animal.
However, amounts of feed refusals were not sufficient to cause actual tarbush consumption to differ substantially from planned treatment levels. Yet, only the highest level of dietary tarbush $(30 \%)$ actually provided measurable nutritional benefits as evidenced by ruminal ammonia and total volatile fatty acids (VFA) levels. Lack of response may be because ruminal ammonia values were consistently above the $5 \mathrm{mg} \mathrm{dl}^{-1}$ necessary for maximal microbial growth (Satter and Slyter 1974).

Tarbush leaves contained substantial concentrations of phenolics (54 mg g $\left.{ }^{-1} \mathrm{DM}\right)$ and condensed tannins $\left(0.40 \mathrm{mg} 100 \mathrm{mg}^{-1}\right.$ DM). Tarbush leaves contained more total phenolics than did 6 other common Chihuahuan Desert shrubs reported by Holechek et al. (1990), including creosotebush (Larrea tridentata [DC.] Cov.). The fact that only a small proportion of tarbush phenolics was accounted for by condensed tannins may indicate the presence of hydrolyzable tannins.

Holechek et al. (1990) reported soluble phenolics have variable impacts on dry matter intake (DMI), depending on concentration. In our study, high phenolic concentrations and associated sorting did not reduce DMI of sheep. In fact, except during the first week, sheep on the 2 highest levels of tarbush tended to have or had the greatest DMI. Sheep on 30\% tarbush exhibited voluntary intakes of approximately $2 \%$ of body weight (BW) except during week 1 .

In situ disappearance of associated dietary fiber was of interest because several tarbush secondary metabolites belong to groups known to interfere with digestion. Proanthocyanidin-protein complexes have been shown to inhibit dry matter (DM) (Kumar and

Table 5. Effect of dietary tarbush on ruminal $\mathrm{pH}$, total volatile fatty acid (VFA) concentrations, and molar proportions of VFA in sheep fed a low

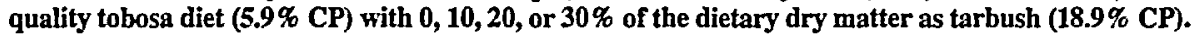

\begin{tabular}{|c|c|c|c|c|c|c|}
\hline \multirow[b]{2}{*}{ Item } & \multicolumn{4}{|c|}{ Treatments } & \multirow[b]{2}{*}{$S E^{2}$} & \multirow[b]{2}{*}{$O S L^{3}$} \\
\hline & $\begin{array}{c}0 \% \\
\text { Tarbush }\end{array}$ & $\begin{array}{c}10 \% \\
\text { Tarbush }\end{array}$ & $\begin{array}{c}20 \% \\
\text { Tarbush }\end{array}$ & $\begin{array}{c}30 \% \\
\text { Tarbush }\end{array}$ & & \\
\hline $\mathrm{pH}$ & 6.7 & 6.7 & 6.8 & 6.7 & 0.04 & 0.2588 \\
\hline Total VFA, mM & $54.6^{\mathrm{a}}$ & $53.3^{\mathrm{a}}$ & $53.0^{\mathrm{a}}$ & $64.7^{\mathrm{b}}$ & 2.14 & 0.0064 \\
\hline \multicolumn{7}{|c|}{ 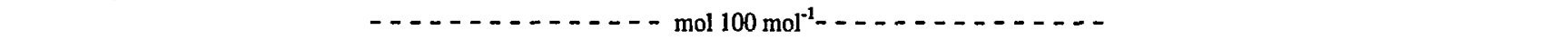 } \\
\hline Acetate & 73.1 & 72.5 & 71.8 & 71.5 & 0.50 & 0.1674 \\
\hline Propionate & 17.3 & 18.2 & 17.7 & 16.8 & 0.56 & 0.3542 \\
\hline Isobutyrate & 2.2 & 2.2 & 2.3 & 2.2 & 0.11 & 0.9065 \\
\hline Butyrate $^{3}$ & $5.2^{\mathrm{a}}$ & $5.0^{\mathrm{a}}$ & $5.7^{\mathrm{a}}$ & $6.9^{b}$ & 0.30 & 0.0032 \\
\hline Isolvalerate & 1.6 & 1.6 & 1.8 & 1.8 & 0.08 & 0.1361 \\
\hline Valerate & $0.7^{2}$ & $0.7^{\mathrm{a}}$ & $0.8^{\mathrm{ab}}$ & $0.9^{\mathrm{b}}$ & 0.04 & 0.0137 \\
\hline
\end{tabular}

3. Least Square Means within row without a common superseript differ $(P<0.05)$.

${ }^{1}$ Standard error of Least Square Means, $n=16$.

${ }_{3}^{2}$ Observed significance level of $F$-statistic for treatment.

${ }^{3} \mathrm{~A}$ time by treatment interaction was observed $(P=0.0419)$. 
Singh 1984) and N digestion (Nastis and Malechek 1981). Also, sagebrush (Artemisia spp.) terpenoids, similar to those embedded in tarbush leaf waxes (Estell et al. 1994), are known to affect ruminal microbes (Striby et al. 1987).

Lack of negative effects of tarbush secondary metabolites on ruminal function (digesta kinetics, in situ degradation) was encouraging, but dietary crude protein (CP) from tarbush leaves did not stimulate digestive functions until tarbush was $30 \%$ of the diet. Possibly, tarbush $\mathrm{N}$ was not fully available due to intrinsic anti-quality factors and/or structural inhibition. Alternatively, an energy deficiency due to the poor quality basal diet may have taken precedence over microbial $\mathrm{N}$ requirements. The nature of tobosa fiber may have contributed to an energy shortage posing as much of a problem as the low CP content of this grass, as evidenced by low rate and extent of in situ neutral detergent fiber (NDF) disappearance. Values for in situ disappearance of tobosa NDF did not approach $33 \%$ until 72 hours of incubation, while ruminal particulate retention times were less than 72 hours for all treatments.

In situ degradation of tarbush $\mathrm{N}$ was minimal until between 12 and 18 hours of incubation, and only $25 \%$ or less of the tarbush $\mathrm{N}$ was in the rapidly degradable fraction. The slow degradation coupled with relatively rapid passage may have prevented increased ruminal ammonia concentrations. Condensed tannins have been reported to reduce ruminal ammonia concentrations (Waghorn et al. 1987, Terrill et al. 1992). However, the highest tarbush intake, and consequently the greatest condensed tannin intake, resulted in increased ruminal ammonia concentrations.

Blood chemistry was consistent with observed body weight (BW) losses, and both confirmed sheep were nutritionally stressed. However, serum clinical profiles provided no evidence of overt toxicosis other than a slight elevation of serum gammaglutamyltransferase for sheep fed tarbush. Diffuse apoptosis of hepatic cells was observed by Frederickson et al. (1994) for lambs fed pellets containing $15 \%$ tarbush (dmb) for 122 days. However, feeding tarbush to lambs at up to $30 \%$ of the diet for 28 days appeared to be safe under the constraints of this study.

In conclusion, nutrients in tarbush, especially crude protein (CP) did not appear to be fully available to sheep. Sheep consuming a low quality grass diet obtained measurable nutritional benefit from tarbush only when leaves constituted $30 \%$ of the diet. This level would be difficult to achieve in free-ranging animals. However, it does appear that modest consumption of tarbush for up to 1 month does not pose a serious health threat to sheep.

\section{Literature Cited}

Anderson, D.M. and J.L. Holechek. 1983. Diets obtained from esophageally fistulated heifers and steers simultaneously grazing semidesert tobosa rangeland. Proc. West. Sec. Amer. Soc. Anim.. Sci.. 34:161-163.

Anderson, D.M., R.P. Gibbens, C.V. Mulet, K.M. Havstad, and R.E. Estell. 1991. Browsing arid rangeland shrubs under multispecies management strategies. IV. Int. Rangeland Congr. No. 188 (Abstr.).

AOAC. 1984. Official Methods of Analysis (14th ed.) Assoc. Official Anal. Chemists. Washington, D.C.

Broderick, G.A. and J.H. Kang. 1980. Automated simultaneous determination of ammonia and total amino acids in ruminal fluid and in vitro media. $J$. Dairy Sci. 63:44-49.

Buffington, L.C. and C.H. Herbel. 1965. Vegetational changes on a semidesert grassland range. Ecol. Monogr. 35:139-149.

Burns, R.E. 1971. Method for estimation of tannin in grain sorghum. Agron. J. 63:511-519.

Estell, R.E., K.M. Havstad, E.L. Frederickson, and J.L. GardeaTorresdey. 1994. Secondary chemistry of the leaf surface of Flourensia cermua. Biochem. Syst. Ecol. 22:73-77.

Frederickson, E., J. Thilsted, R. Estell, and K. Havstad. 1994. Effect of chronic ingestion of tarbush (Flourensia cernua) on ewe lambs. Vet. Human Toxicol. 36(5):409-415.
Gill, J.L., and H.D. Hafs. 1971. Analysis of repeated measurements of animals. J. Anim. Sci. 33:331-338.

Goering, H.K. and P.J. Van Soest. 1970. Forage fiber analysis (apparatus, reagents, procedures and some applications). USDA-ARS Handb. No. 379., Washington, D.C.

Goetsch, A.L. and M.L. Galyean. 1983. Influence of feeding frequency on passage of fluid and particulate markers in steers fed a concentrate diet. Can. J. Anim. Sci. 63:727-738.

Hailey, T.L., J.W. Thomas, and R.M. Robinson. 1966. Pronghorn die-off in Trans-Pecos Texas. J. Wild. Manage. 30:488-595.

Hart, S.P. and C.E. Polan. 1984. Simultaneous extraction and determination of ytterbium and cobalt ethylenediaminetetra-acetate complex in feces. J. Dairy Sci. 67:888-895.

Holechek, J.L., A.V. Munshikpu, L. Saiwana, G. Nunez-Hernandez, R. Valdez, J.D. Wallace, and M. Cardenas. 1990. Influences of six shrub diets varying in phenol content on intake and nitrogen retention by goats. Trop. Grassl. 24:93-98.

Kaneko, J.J. 1989. Clinical biochemistry of domestic animals, fourth edition. Academic Press Inc., New York, N.Y.

King, D.W., E.L. Fredrickson, R.E. Estell, K.M. Havstad, J.D. Wallace, and L.W. Murray. 1996. Effects of tarbush (Flourensia cernua DC) ingestion on nitrogen balance of sheep consuming low quality tobosa grass diets. J. Range Manage. 49:331-335.

Krysl, L.J., F.T. McCollum, and M.L. Galyean. 1985. Estimation of fecal output and particulate passage rate with a pulse dose of Ytterbium-labeled forage. J. Range Mange. 38:180-182.

Kumar, $R$. and M. Singh. 1984. Tannins: their adverse role in ruminant nutrition. J. Agr. Food Chem. 32:447-453.

Mathews, F.P. 1944. The toxicity of the ripe fruit of blackbrush or tarbush (Flourensia cernua) for sheep and goats. Tex. Agr. Exp. Sta. Bull. No. 664 .

MicCollum, F.T. and M.L. Galyean. 1985. Influence of cottonseed meal supplementation on voluntary intake, rumen fermentation and rate of passage of prairie hay in beef steers. J. Anim. Sci. 60:570-577.

Mertens, D.R. and J.R. Loften. 1980. The effect of starch on forage fiber digestion kinetics in vitro. J. Dairy Sci. 63:1437-1444.

Moore, J.A., M.H. Poore, and R.S. Swingle. 1987. Time-saving procedure for determining dry matter (DM) and neutral detergent fiber (NDF) content in residues from in situ incubations. J. Anim. Sci. 65(Suppl. 1):487.

Moshtaghi Nia, S.A. and J.R. Ingalls. 1992. Effect of heating on canola meal protein degradation in the rumen and digestion in the lower gastrointestinal tract of steers. Can. J. Anim. Sci. 72:83-88.

Nastis, A.S. and J.C. Malechek. 1981. Digestion and utilization of nutrients in oak browse by goats. J. Anim. Sci. 53:283-289.

Nelson, A.B., C.H. Herbel, and H.M. Jackson. 1970. Chemical composition of forage species grazed by cattle on arid New Mexico range. N.M. Agr. Exp. Sta. Bull. No. 561 .

Nocek, J.E. 1988. In situ and other methods to estimate ruminal protein and energy digestion: a review. J. Dairy Sci. 71:2051-2069.

O'Laughlin, T.C. 1975. The distribution and productivity of Flourensia cernua D.C. in southem New Mexico. M.S. Thesis, New Mexico State Univ., Las Cruces, N.M.

Grskov, E.R. 1992. Protein nutrition in ruminants, second edition. Academic Press Inc., New York, N.Y.

Qrskov, E.R., and I. McDonald. 1979. The estimation of protein degradability in the rumen from incubation measurements weighted according to rate of passage. J. Agr. Sci. (Camb.) 92:499-503.

Price, M.I., S. Van Scoyoc, and L.G. Butler. 1978. A critical evaluation of the vanillin reaction as an assay for tannin in sorghum grain. J. Agr. Food Chem. 26:1214-1219.

SAS Institute. 1989. SAS User's Guide: Statistics, Version 6.07. SAS Institute, Inc. Cary, N.C.

Satter, L.D. and L.L. Slyter. 1974. Effect of ammonia concentration on rumen microbial production in vitro.. Brit. J. Nutr. 32:199-208.

Striby, K.D., C.L. Wambolt, R.G. Kelsey, and K.M. Havstad. 1987. Crude terpenoid influence on in vitro digestibility of sagebrush. J. Range Manage. 40:244-248.

Terrill, T.H., G.B. Douglas, A.G. Foote, R.W. Purchas, G.F. Wilson, and T.N. Barry. 1992. Effect of condensed tannin upon body growth, wool growth and rumen metabolism in sheep grazing sulla (Hedysanum coronium) and perennial pasture. J. Agr. Sci. (Camb.) 119:265-273.

Teeter, R.G., F.N. Owens, and T.L. Mader. 1984. Ytterbium chloride as a marker for particulate matter in the rumen. J. Anim. Sci. 58:465-470.

Uden, P., P.E. Colucci, and P.J. Van Soest. 1980. Investigation of chromium, cerium and cobalt as markers in digesta. Rate of passage studies. J. Sci. Food Agr. 32:625-632.

Waghorn, G.C., M.J. Ulyatt, A. John, and M.T. Fisher. 1987. The effect of condensed tannins on the site of digestion of amino acids and other nutrients in sheep fed on Lotus corniculatus L. Brit. J. Nutr. 57:115-126. 